\title{
Early life determinants of physical activity and sedentary time: Current knowledge and future research
}

\author{
Guro Pauck Øglund, Trine Stensrud and Ulf Ekelund \\ The Norwegian School of Sport Sciences, Department of Sport Medicine, PB 4014 Ullevål Stadion, 0806 Oslo, Norway \\ Correspondence: Ulf Ekelund, E-mail: ulf.ekelund@nih.no, telephone: +4740629589
}

\begin{abstract}
Previous findings of the association between low birth weight and subsequent health outcomes have led to the "developmental origins of health and disease hypothesis". Furthermore, modifiable and partly modifiable early life factors may also influence behaviors such as physical activity and sedentary behavior. The aim of the present review was to summarize the existing knowledge on early life determinants (birth weight, rapid infant weight gain, motor development and infant temperament) of childhood physical activity and sedentary time, and suggest opportunities for future research based on the Mother and Child Cohort Study (MoBa). Inconsistent results have been observed when relating birth weight to later physical activity, likely explained by differences in methodology when assessing physical activity between studies. There is limited data on whether rapid weight gain in early life predicts later physical activity and few studies have examined the association between birth weight and infant weight gain with subsequent sedentary time. Motor development may be a predictor for childhood physical activity, however methodological limitations preclude firm conclusions. The association between motor development and sedentary time has rarely been examined. Conflicting results have been reported for the association between infant temperament and subsequent physical activity and sedentary time in toddlers. Finally, it is unknown whether physical activity modifies the association between birth weight, postnatal weight gain, and later health outcomes in youth. Additional research in well-characterized birth cohorts can be used to generate new knowledge on possible early life determinants of children's and youth's physical activity and sedentary time which may inform evidence-based public health interventions.
\end{abstract}

This is an open access article distributed under the Creative Commons Attribution Licence, which permits unrestricted use, distribution, and reproduction in any medium, provided the original work is properly cited.

\section{INTRODUCTION AND BACKGROUND}

Until a few decades ago there was a conception that non-communicable diseases (NCD), including hypertension, cardiovascular diseases, obesity and type 2 diabetes, were determined by genetic predisposition and lifestyle behaviors. However, findings from research linking intrauterine and early postnatal environmental factors with subsequent disease outcomes, suggest that a life-course approach is necessary to more completely understand the development of some NCD $(1,2)$. This has led to the "developmental origins of health and disease (DOHAD) hypothesis" $(3,4)$, suggesting that many NCD at least partly have their origin in utero or during early life (4-6). The impetus to this hypothesis are findings suggesting an association between low birth weight, used as a marker of fetal growth restriction, and increased risk of cardiovascular diseases $(2,7-9)$, hypertension $(1,10)$ and type 2 diabetes $(11,12)$. Additional research has linked both low and high birth weight to subsequent obesity (13), and rapid infant weight gain to hypertension (10), cardiovascular disease $(14,15)$, clustering of metabolic risk factors in children $(15,16)$ and obesity $(17-20)$.

Factors early in life may also influence lifestyle behaviors, such as physical activity and sedentary time (21). This association is less well-explored. The main aim for many of the existing birth-cohorts, e.g. the
Norwegian Mother and Child Cohort study (MoBastudy), is to study the development and determinants of diseases in the human population $(22,23)$. However, birth-cohorts are also ideally suited to explore early life determinants of behaviors such as physical activity and sedentary time. Since these lifestyle behaviors are associated with beneficial health outcomes already in apparently healthy young people (24-28), increased knowledge about their potential early life determinants may provide valuable knowledge to aid future intervention programs and public health prevention strategies.

Recent data from relatively large cross-sectional studies suggest that total physical activity $(24,29,30)$, and time spent in moderate-to-vigorous physical activity (MVPA) (26) are inversely associated with clustering of cardio-metabolic risk factors (i.e. blood pressure, insulin levels, glucose, fasting triglycerides, inverted high-density lipoprotein (HDL) cholesterol). Some of these studies have also shown that this association is independent of adiposity and other potential confounding factors $(26,29)$. Furthermore, physical activity, and especially MVPA and vigorous physical activity (VPA), is inversely associated with adiposity $(24,27,31,32)$ and waist circumference $(26,31)$. However, most of the existing knowledge is based on crosssectional observational studies and there is paucity of prospective data limiting the possibility to address temporal associations and indicating stronger inference 
for causality compared with cross-sectional studies. Whether time spent sedentary and sedentary behaviors are associated with health indicators is less consistent. Cross-sectional studies have suggested an association between objectively measured sedentary time and adiposity (27,31-33) and cardio-metabolic risk factors (26) in children. However, these associations were attenuated after further adjustment for physical activity, time spent in MVPA or VPA $(26,27,31)$. In contrast, TV-viewing (a proxy for sedentary behavior) has been associated with risk factors for type 2 diabetes $(29,34)$, although some have suggested the relationship may be mediated by adiposity (29). Taken together, it appears that specific sedentary behaviours, such as watching $\mathrm{TV}$, is more closely related to health indicators than total amount of sedentary time $(27,35)$. It has also been suggested that the association between time watching TV and adiposity is mediated by other behaviors, such as snacking while watching TV (27). Thus, some national authorities have proposed that screen time in youth should be limited to less than two hours per day $(36,37)$.

According to the Norwegian Guidelines for Nutrition and Physical Activity children and youth are recommended to participate in at least 60 minutes of MVPA per day. Furthermore, children and youth are recommended to reduce sedentary time (38). In a nationally representative population from Norway in which physical activity was measured objectively, the prevalence of sufficiently active children and youth were $95.7 \%$ and $87 \%$ in 6 year olds, $86.2 \%$ and $69.8 \%$ in 9 year olds, and $58.1 \%$ and $43.2 \%$ in 15 year olds, boys and girls respectively (39). Longitudinal analysis showed that activity level declined from 9 to 15 years (39). Due to various definitions of MVPA when assessed objectively, the prevalence of sufficiently active children and youth (6 to 15 years) varies from $99.6 \%$ to $0.4 \%$ in comparable studies (40-46). Using a similar definition as adopted in the Norwegian youth, Owen et al. (46) suggested that $76 \%$ and $53 \%$ of $9-10$ year old boys and girls, from a multi-ethnic district in England, met the recommended levels of physical activity. Whereas Pate et al. (43) suggested that no more than $11.8 \%$ of 12 year old girls from the US were active according to the recommendations for public health. It appears that boys are more physical active than girls $(39,40,42,44-$ $47)$, and that activity level declines with age (39-42, $47)$, also confirmed in longitudinal analysis $(39,41)$. Children and youth from Norway, England and European countries spent between 376 and 576 minutes sedentary per day, when measured by accelerometry $(39,44-46)$. In the Norwegian sample this corresponds to approximately $50 \%$ of the day (when the monitor is worn) in 6 year olds, whereas sedentary time exceeded $70 \%$ of the day in 15 year olds. Furthermore, girls appears to spend more time sedentary than boys in all age-groups (39).

Given the associations between physical activity and health outcomes in young people, and since children spend a substantial amount of time every day sedentary, it is important to identify factors (correlates and determinants) that potentially influence these lifestyle behaviors. A correlate refers to a factor associated with physical activity and sedentary time, however, the causality of the association is unclear (48). On the other hand, a factor that is associated with change in physical activity or sedentary time, from longitudinal observational research or randomized controlled trials, is defined as a determinant $(48,49)$. Several possible correlates and determinants of physical activity have been identified, including individual and biological (being boy, white ethnic origin), psychosocial (self-efficacy, perceived competence, perceived behavioral control), behavioral (previous physical activity) and environmental factors (walkability, little amount of traffic, proximity to homes and shops, residential density) $(50,51)$. Less research has been conducted to identify possible determinants of sedentary time and behavior, and the evidence is inconclusive (52). Age, ethnicity and maturity have been related to sedentary time (53), whereas lower socioeconomic status, family and parental TV-viewing, lack of parental rules, number of TV and computers in household, TV in bedroom and unlimited screen time has been associated with sedentary behavior $(53,54)$, although these associations may be less pronounced in younger children ( $\leq 7$ years) (54). A positive association between parental TV habits and young girl's daily TV time has also been observed in longitudinal analysis, which may suggest parental TV habits being a determinant of their daughter's behavior (55).

Most of the research of correlates and determinants of physical activity and sedentary time have focused on behavioral and environmental factors, and there is a paucity of data on early life and biological determinants of these lifestyle behaviors. Therefore, the aim of the present narrative review is to summarize the existing knowledge on early life determinants (birth weight, rapid infant weight gain, motor development and infant temperament) of childhood physical activity and sedentary time, and suggest opportunities for future research.

\section{METHODS}

In the present review we aimed to summarize the available knowledge on four potential early life determinants of later physical activity and sedentary time/behavior; birth weight, infant weight gain, motor development and infant temperament. A literaturesearch was performed in PubMed and PsycINFO. The following terms was included in the search: "birth weight"; "infant weight gain", "motor development", "infant temperament", "early life determinants" in a combination with [AND] "physical activity", "sedentary behavior", "sedentary time" or "TV-viewing". In addition, we examined the reference lists of all relevant articles to search for additional papers that met 
the inclusion criteria.

We included English-written papers that specifically examined the defined early life factors' associations with physical activity and sedentary time/behavior in a healthy population of children/adolescence up to the age of 18 years. One article (56) which examined the associations between birth weight and later physical activity in an older age group (14 to 74 years) was included because results presented in the younger agegroup included adolescents (14 to 34 years).

In total, the literature-search resulted in eight papers (21,56-62) examining birth weight and physical activity and four studies $(58,60-62)$ examining birth weight and sedentary time. Three studies $(59,62,63)$ examined motor development in relation to physical activity, and one study (62) reported results on the association between motor development and sedentary time. Infant temperament's was examined in relation to physical activity in one study (62), and sedentary time/sedentary behavior (TV-viewing) in two $(62,64)$. All included papers were longitudinal observational studies. Two articles $(56,61)$ used a retrospectively reported birth weight whereas all other papers included data on birth weight obtained at birth, either measured $(21,57,58,60$, $62)$ or maternally reported shortly after birth $(59,62)$. Motor development was parentally reported at the age 6 months (59) or 12 months $(62,63)$. In the study by Thompson et al. (64) infant temperament was maternally reported at regular intervals from 3-18 months old, whereas in the study by Wijtzes et al. (62), infant temperament was parentally reported at the age 6 months. See Table 1 for summary of study designs and results.

\section{RESULTS AND DISCUSSION}

\section{Birth weight}

Animal experiments imply that under-nutrition in fetal life, followed by postnatal weight gain, is associated with reduced motor activity $(65,66)$ and increased sedentary behavior (67). Some human data tend to support these observations. Individuals born pre-term with a very low birth weight $(<1500 \mathrm{~g})(68,69)$, and extremely low birth weight $(\leq 800 \mathrm{~g})(70)$, reported less participation in leisure time physical activity in adolescence and adulthood, compared to those born at term. However, this association may be mediated by lower cardio-respiratory fitness and/or lower muscle mass in those born prematurely. A meta-analysis of 13 cohorts (Table 1) suggested a reversed U-shaped association between birth weight and self-reported leisure time physical activity, however this association was no longer significant when stratified by gender and agegroup (56). A particular strength of this meta-analysis is the large sample size including men and women varying in age and activity levels. However metaanalyzing results from different cohorts in which physical activity have been self-reported with different instruments is problematic and may introduce bias. One additional study suggested a weak but statistically significant positive association between birth weight and self-reported physical activity in 10-12 year olds from Pelotas in Southern-Brazil (21). In contrast, none of the studies in which physical activity was assessed by an objective method observed any association between birth weight and later physical activity (Table 1) (57-62). One of the studies (62) may have been limited in power since the low birth weight group $(<2500 \mathrm{~g})$, which was compared to the reference group (normal birth weight), only included nine participants. In addition, although physical activity and sedentary time were measured objectively, the accelerometer was only worn for two days, one weekday and one weekend day. Much stronger inference of a non-significant association between birth weight and physical activity comes from the Avon Longitudinal Study of Parents and Children (ALSPAC) which included 5058 children in which physical activity was objectively measured at age 11-12 years (59). The meta-analysis by Ridgway et al. (61) included four studies, three cohorts from Europe and one from Southern Brazil (Table 1). The combined meta-analysis confirmed previous observations and suggested no association between birth weight and later physical activity, but when cohorts were analyzed separately, the results from one of the cohorts (from Southern Brazil) suggested an association between higher birth weight and lower levels of physical activity and increased sedentary time, although attenuated after adjustment for gestational age. Taken together, it may be that the association between birth weight and subsequent physical activity is limited to those born with very low birth weight (68-70). Few studies have examined the associations between birth weight and sedentary time, and no association was observed $(58,60-62)$. However, the studies by Pearce et al. (60) and Wijtzes et al. (62) may be limited by their definition of objectively measured sedentary time due to a remarkably high threshold. It is likely these studies misclassified a substantial amount of sedentary time as light intensity activity $(71,72)$.

\section{Infant weight gain}

Low birth weight is usually associated with a rapid infant weight gain, as those who are born small or thin often compensate with a rapid postnatal weight gain (19). It has been suggested that postnatal and early childhood rapid weight gain, rather than birth weight and size at birth per se, is more strongly associated with subsequent health outcomes, particularly obesity $(19,73)$. And it could be hypothesized that rapid infant weight gain promote subsequent adiposity (17-19), and contribute to lower levels of physical activity and increased sedentary time in youth. This is because adiposity appears to predict lower levels of physical activity $(74,75)$. Hallal et al. examined infant weight gain with subsequent self-reported physical activity in 10-12 year olds (21), and objectively assessed physical activity and sedentary time in 13 year olds (58), from the Pelotas cohort study (Table 1). None of the defined 
Table 1. Longitudinal observational studies examining the association between early life factors and physical activity and sedentary time/behavior in children/adolescents.

\begin{tabular}{|c|c|c|c|c|c|}
\hline Reference & Study population & $\begin{array}{l}\text { Follow-up } \\
\text { period }\end{array}$ & Exposure (assessment) & Outcome (assessment) & Summary of results \\
\hline \multicolumn{6}{|c|}{ Birth weight and infant weight gain } \\
\hline Andersen et al. (56) & $\begin{array}{l}\text { Nordic countries, } 13 \\
\text { cohorts (n=43 482) } \\
24890 \text { men, } 18592 \\
\text { women }\end{array}$ & $\begin{array}{l}\text { Birth up to } 74 \text { years } \\
\text { Younger group, } \\
14-34 \text { years }\end{array}$ & $\begin{array}{l}\text { Birth weight, maternally } \\
\text { reported or measured } \\
\text { (retrospective and } \\
\text { prospective) }\end{array}$ & $\begin{array}{l}\text { LTPA: self-reported } \\
\text { (active/inactive) }\end{array}$ & $\begin{array}{l}\text { Low birth weight and high birth weight was } \\
\text { not associated with lower probabilities of } \\
\text { being active when stratified by age-group } \\
\text { and gender. } \\
\text { (adjusted for gestational age, education, } \\
\text { body mass index, smoking status) }\end{array}$ \\
\hline Campbell et al. (57) & $\begin{array}{l}\text { Kingston, Jamaica } \\
(\mathrm{n}=569) \\
\text { The Vulnerable } \\
\text { Windows Cohort Study } \\
124 \text { boys, } 160 \text { girls }\end{array}$ & Birth to 13 years & Birth weight, measured & $\begin{array}{l}\text { PA: objectively assessed } \\
\text { with Actical monitor } \\
\text { Average cpm }\end{array}$ & No association \\
\hline Hallal et al. (21) & $\begin{array}{l}\text { Southern Brazil } \\
(\mathrm{n}=4453) \\
\text { Pelotas-cohort } \\
2167 \text { boys, } 2283 \text { girls }\end{array}$ & $\begin{array}{l}\text { Birth to 10-12 } \\
\text { years }\end{array}$ & $\begin{array}{l}\text { Birth weight, measured } \\
\text { Weight gain, measured, } \\
\text { from birth-1year, lyear- } \\
\text { 4years and 4-11years }\end{array}$ & $\begin{array}{l}\text { PA: self-reported } \\
\text { (min/week) and inactive } \\
\text { lifestyle }(>300 \mathrm{~min} / \text { week } \\
\text { in PA) }\end{array}$ & $\begin{array}{l}\text { A small positive association between birth } \\
\text { weight and physical activity }(\mathrm{p}=0.05) \text {, } \\
\text { crude analysis. } \\
\text { No association between weight gain and } \\
\text { physical activity or inactive lifestyle. }\end{array}$ \\
\hline Hallal et al. (58) & $\begin{array}{l}\text { Southern Brazil }(n=457) \\
\text { Pelotas- cohort } \\
52,1 \% \text { boys }\end{array}$ & Birth to 13 years & $\begin{array}{l}\text { Birth weight, measured } \\
\text { Weight gain, measured, } \\
\text { from birth-1months, } 3 \\
\text { months, } 6 \text { months, } 1 \text { year } \\
\text { and } 4 \text { years }\end{array}$ & $\begin{array}{l}\text { PA and SED: objectively } \\
\text { assessed with Actigraph } \\
\text { accelerometer } \\
\text { Cut-points: } \\
\text { SED: } \leq 100 \mathrm{cpm} \\
\text { MVPA: }>2000 \mathrm{cpm}\end{array}$ & No association \\
\hline Mattocks et al. (59) & $\begin{array}{l}\text { Avon, United Kingdom } \\
(\mathrm{n}=5451) \\
\text { ALSPAC } \\
2593 \text { boys, } 2858 \text { girls }\end{array}$ & $\begin{array}{l}\text { Birth to 11-12 } \\
\text { years }\end{array}$ & $\begin{array}{l}\text { Birth weight, reported } \\
\text { Ponderal index }\left(\mathrm{kg} / \mathrm{m}^{3}\right)\end{array}$ & $\begin{array}{l}\text { PA: objectively assessed } \\
\text { with Actigraph } \\
\text { accelerometer (average } \\
\text { cpm) }\end{array}$ & No association \\
\hline Pearce et al. (60) & $\begin{array}{l}\text { Gateshead, England } \\
(\mathrm{n}=482) \\
\text { GMS } \\
231 \text { boys, } 251 \text { girls }\end{array}$ & Birth to $8-10$ years & Birth weight, measured & $\begin{array}{l}\text { PA and SED: objectively } \\
\text { assessed with Actigraph } \\
\text { accelerometer } \\
\text { Cut-points: } \\
\text { SED: }<1100 \mathrm{cpm} \\
\text { MVPA: }>3200 \mathrm{cpm}\end{array}$ & No association \\
\hline Ridgway et al. (61) & $\begin{array}{l}4 \text { studies: } \\
\text { EYHS: European } \\
\text { countries }(\mathrm{n}=1240) \\
\text { Roots: UK }(\mathrm{n}=811) \\
\text { Speedy: UK }(\mathrm{n}=1647) \\
\text { Pelotas: Southern Brazil } \\
(\mathrm{n}=5246)\end{array}$ & $\begin{array}{l}\text { EYHS: } 9 \text { and } 15 \\
\text { years } \\
\text { Roots: } 13-15 \text { years } \\
\text { Speedy: } 9-10 \text { years } \\
\text { Pelotas: Birth to } \\
\text { 12-14 years }\end{array}$ & $\begin{array}{l}\text { Birth weight, retrospective } \\
\text { maternally reported in } \\
\text { EYHS, Roots and Speedy. } \\
\text { Measured at birth in Pelotas. }\end{array}$ & $\begin{array}{l}\text { PA and SED: objectively } \\
\text { assessed with Actigraph } \\
\text { (EYHS, Speedy, Pelotas) } \\
\text { and Actiheart (Roots) } \\
\text { Cut-points: } \\
\text { SED }<100 \mathrm{cpm} \\
\text { MVPA }<2000 \mathrm{cpm}\end{array}$ & No association in the combined analysis \\
\hline Wijtzes et al. (62) & $\begin{array}{l}\text { Rotterdam, Netherland } \\
(\mathrm{n}=347) \\
\text { The Generation } \mathrm{R} \\
182 \text { boys, } 165 \text { girls }\end{array}$ & Birth to 2 years & $\begin{array}{l}\text { Birth weight, from delivery } \\
\text { reports or maternally } \\
\text { reported } 2 \text { months post- } \\
\text { partum. }\end{array}$ & $\begin{array}{l}\text { PA and SED:objectively } \\
\text { assessed with uniaxial } \\
\text { Actigraph accelerometer. } \\
\text { Cut-points: } \\
\text { SED: } \leq 301 \text { counts } / 15 \mathrm{~s} \\
\text { MVPA: }>615 \text { counts } / 15 \mathrm{~s}\end{array}$ & No association \\
\hline \multicolumn{6}{|l|}{ Motor development } \\
\hline Mattocks et al. (59) & $\begin{array}{l}\text { Avon, United Kingdom } \\
(\mathrm{n}=5451) \\
\text { ALSPAC } \\
2593 \text { boys, } 2858 \text { girls }\end{array}$ & $\begin{array}{l}\text { Birth to 11-12 } \\
\text { years }\end{array}$ & $\begin{array}{l}6 \text { months: maternally } \\
\text { reported motor coordination, } \\
\text { combined score }\end{array}$ & $\begin{array}{l}\text { PA: objectively assessed } \\
\text { with Actigraph } \\
\text { accelerometer (average } \\
\text { cpm) }\end{array}$ & $\begin{array}{l}\text { Motor coordination at } 6 \text { months associated } \\
\text { with PA at } 11-12 \text { years. } \beta(95 \% \mathrm{CI}) \\
5.77(0.25,11.29), \mathrm{p}=0.041 \text { (adjusted for } \\
\text { age, sex, parental social class, mothers } \\
\text { education). }\end{array}$ \\
\hline Ridgway et al. (63) & $\begin{array}{l}\text { Oulu and Lapland, } \\
\text { Finland (n=9009) } \\
\text { NFBC } 1966\end{array}$ & Birth to 14 years & $\begin{array}{l}12 \text { months: parental report of } \\
\text { age at walking supported } \\
\text { and age at first standing } \\
\text { unaided }\end{array}$ & $\begin{array}{l}\text { Sport participation: self- } \\
\text { reported PE grade, } \\
\text { participation in number of } \\
\text { different sports and } \\
\text { frequency of sport } \\
\text { participation per week }\end{array}$ & $\begin{array}{l}\text { Age at walking supported (months) } \\
\text { associated with frequency of sports } \\
\text { participation } \beta(95 \% \mathrm{CI}) ;-0.04(-0.09,0.00) \text {, } \\
\text { participating in number of different sports - } \\
0.03(-0.05,-0.01) \text { and PE grade }-0.06(- \\
0.08,-0.04) \text { (adjusted for sex, gestational } \\
\text { age, birth season, fathers' social class, birth } \\
\text { weight and BMI). } \\
\text { Age at standing unaided (months) } \\
\text { associated with PE grade }-0.06(-0.09,-0.04) \\
\text { (adjusted for sex, gestational age, birth } \\
\text { season, fathers' social class, birth weight } \\
\text { and BMI) }\end{array}$ \\
\hline Wijtzes et al. (62) & $\begin{array}{l}\text { Rotterdam, Netherland } \\
(\mathrm{n}=347) \\
\text { The Generation R- } \\
\text { cohort } \\
182 \text { boys, } 165 \text { girls }\end{array}$ & Birth to 2 years & $\begin{array}{l}12 \text { months: parentally } \\
\text { reported gross motor } \\
\text { development, } \\
\text { (normal/delayed) } \\
\text { Gross motor' scale, } \\
\text { Minnesota Infant } \\
\text { Development Inventory. }\end{array}$ & $\begin{array}{l}\text { PA and SED: objectively } \\
\text { assessed with uniaxial } \\
\text { Actigraph accelerometer. } \\
\text { Cut-points: } \\
\text { SED: } \leq 301 \text { counts } / 15 \mathrm{~s} \\
\text { Total PA: average } \mathrm{cpm} / \text { day } \\
\text { MVPA: }>615 \text { counts } / 15 \mathrm{~s}\end{array}$ & $\begin{array}{l}\text { Crude analysis: Association } \beta(95 \% \mathrm{CI}) \\
\text { between delayed motor development and } \\
\text { sedentary time } 1.2(0.2,2.3) \text {, and inverse } \\
\text { association with MVPA and total PA, }-0.7(- \\
1.2,-0.1) \text { and }-46.2(-83.3,-9.2) \text { respectively. } \\
\text { No association after adjustment for sex, } \\
\text { age, number of siblings and season }\end{array}$ \\
\hline
\end{tabular}




\begin{tabular}{|c|c|c|c|c|c|}
\hline Reference & Study population & $\begin{array}{l}\text { Follow-up } \\
\text { period }\end{array}$ & Exposure (assessment) & Outcome (assessment) & Summary of results \\
\hline \multicolumn{6}{|l|}{ Infant temperament } \\
\hline Thompson et al. (64) & $\begin{array}{l}\text { North Carolina, USA. } \\
(\mathrm{n}=217) \\
\text { Infant Care and Risk of } \\
\text { Obesity Study } \\
101 \text { boys, } 116 \text { girls }\end{array}$ & 3 to 18 months & $\begin{array}{l}\text { Maternally reported infant } \\
\text { temperament: } \\
3,6 \text { and } 9 \text { months - activity } \\
\text { and DTL subscales of IBQ- } \\
\text { R, and average crying } \\
\text { duration (hours/day) } \\
12 \text { and } 18 \text { months } \\
\text { postpartum- ECBQ and } \\
\text { average crying duration } \\
\text { (hours/day) }\end{array}$ & $\begin{array}{l}\text { TV-exposure: maternally } \\
\text { reported (hours/day): } \\
\text { (1) Dichotomous variable } \\
\text { (Any TV, yes } \geq 1 \text { hour/day) } \\
\text { (2) } 3 \text {-level variable (TV- } \\
\text { group } 0 \text { to }<1 \text { hour, } 1-3 \\
\text { hours, and }>3 \text { hours/day) }\end{array}$ & $\begin{array}{l}\text { Any TV associated with daily crying } \\
\text { duration OR }(95 \% \mathrm{CI}) ; 1.10(1.02,1.47) \\
\text { (adjusted for infant gender and age). } \\
\text { TV-group associated with activity OR } \\
(95 \% \mathrm{CI}) ; 1.42(1.12,1.79) \text { and daily crying } \\
\text { duration } 1.10(1.01,1.19) \text { (adjusted for } \\
\text { infant gender and age, socio-economic } \\
\text { status). }\end{array}$ \\
\hline Wijtzes et al. (62) & $\begin{array}{l}\text { Rotterdam, Netherland } \\
(\mathrm{n}=347) \\
\text { The Generation } \mathrm{R}- \\
\text { cohort } \\
182 \text { boys, } 165 \text { girls }\end{array}$ & Birth to 2 years & $\begin{array}{l}6 \text { months: parentally } \\
\text { reported infant } \\
\text { temperament, IBQ-R }\end{array}$ & $\begin{array}{l}\text { PA and SED: objectively } \\
\text { assessed with uniaxial } \\
\text { Actigraph accelerometer. } \\
\text { Cut points: } \\
\text { SED: } \leq 301 \text { counts } / 15 \mathrm{~s} \\
\text { Total PA: average } \mathrm{cpm} / \text { day } \\
\text { MVPA: }>615 \text { counts } / 15 \mathrm{~s}\end{array}$ & No association \\
\hline
\end{tabular}

cpm: Counts per minute, DLT: Distress to limitation, ECBQ: Early Childhood Behavior Questionnaire, IBQ-R: Infant Behavior QuestionnaireRevised, LTPA: Leisure time physical activity, MVPA: Moderate to vigorous physical activity, PA: Physical activity, SED: Sedentary time/behavior

weight-gain periods were associated with physical activity $(21,58)$ or sedentary time $(58)$. However, it is possible that early life factors influence lifestyle behaviors differently in developing and developed countries, although this has rarely been explored.

\section{Motor development}

During the first year of life movement capabilities changes dramatically and the infant achieve several developmental motor milestones, e.g. sitting alone, crawling, standing unaided and eventually walking (76). Stodden et al. (77) hypothesized that physical activity in early childhood is driven by their development of motor skills. Suggesting that early motor development is associated with physical activity, which further influences motor skills, and a positive spiral occurs. Infant motor development has been associated with physical performance at age 31 years (78), and standing balance, chair raising (79) and handgrip strength (80) at age 53 years. Ridgway et al. (63) examined the association between age at reaching certain developmental milestones and self-reported sport participation at age 14 (Table 1). Age at walking supported was associated with higher sport participation (PE grade, frequency of sport participation, participation in number of different sports), and earlier age at standing unaided was associated with higher physical education (PE) grades. However, these results did only consider self-reported sport participation and PE grades and it is likely children may be active without participating in sports. Further, it is unclear whether PE grades are a good proxy for habitual physical activity. Mattocks et al. (59) found an association between motor coordination at six months and overall physical activity in 1112 year olds, after adjustment for age, sex, parental social class and maternal education. A major strength of this study was the inclusion of objectively measured physical activity in a large sample of well characterized children. Although the observed associations in these two studies were statistically significant, the magnitudes of associations were relatively small $(59,63)$ (Table 1). Wijtzes et al. (62) examined the association between birth weight, infant temperament and motor development with subsequent objectively assessed physical activity and sedentary time in 2 year olds. The univariate analysis showed a positive association between delayed motor development and sedentary time, and an inverse association between delayed motor development and physical activity. However, the associations were attenuated after adjustment for sex, age, number of siblings and season, and it is a possibility that the sample size were too small to detect any meaningful associations in multivariate analysis. Taken together, there is a tendency that motor development influence subsequent physical activity, however some studies are limited by methodology, e.g. physical activity measurement (63) and relatively small sample size (62). Additional high quality studies are therefore needed to provide sufficient evidence whether early motor development act as a determinant of childhood physical activity and sedentary time.

\section{Infant temperament}

Temperament refers to biologically based individual differences in behavioral style (affect, activity and attention), i.e. the characteristics of an individual's emotional nature (81). Infant temperament may be associated with infant weight gain (82-85), and temperament in early childhood appears to be associated with overweight and obesity later in life (86). Crosssectional (87) and longitudinal data (88) from the MoBa-study, suggest that 18 months old infants who were perceived as sad, anxious, defiant and aggressive were more likely to be given sweet foods and sweet drinks in infancy, at 3 years and 7 years. It has been suggested that the TV (64) and additional feeding (82, $85)$ are used to sooth and entertain the child, and that the TV is used as a "babysitter" (64). Wijtzes et al. (62) 
(Table 1) did not find any association between infant temperament at 6 months and physical activity and sedentary time in 2 year olds. Thompson et al. (64) examined infant temperament and its relation to TVexposure at 18 months. The longitudinal observational study included low-income African-American mothers and infants who were followed-up in their homes at 3 , 6, 9, 12 and 18 months postpartum. Maternal perception of the infant's activity and daily crying duration were associated with increased risk of TV-exposure. When activity, distress to limitation (DTL) and crying duration at 3 months was combined with the mother being obese, and when high infant activity was combined with low maternal education level, the risk of hours per day spent watching TV increased. This may also indicate that obesity and maternal education are possible confounding factors to the association between infant temperament and TV-exposure. However, the association between infant temperament and physical activity and sedentary time in children and youth is currently unknown based on the identified studies, as previous research has been performed in toddlers $(62$, 64). Further, the results are based on maternally reported TV-time (64) and objectively measured physical activity and sedentary time from only two days (62). In addition, the studies are limited by relatively small sample sizes $(62,64)$. To explore whether infant temperament is associated with physical activity and sedentary time in children and youth, cohort-studies with longer follow-up period and with objectively measured physical activity and sedentary time, are warranted. It is also interesting to further examine the association between infant temperament and long-term TV-exposure and whether an observed association may be mediated or confounded by socio-economic status and other parental factors.

\section{DOES PHYSICAL ACTIVITY MODIFY THE ASSOCIATIONS BETWEEN EARLY LIFE DETERMINANTS AND HEALTH OUTCOMES?}

Since birth weight and rapid weight gain in infancy appears associated with later health outcomes (7,1520 ), the question arises whether physical activity act as a modifier on the association between birth weight, accelerated weight gain in infancy and childhood clustering of cardio-metabolic risk factors and adiposity. Laaksonen et al. (89) examined whether self-reported physical activity alleviate or attenuate the association between ponderal index at birth $\left(\mathrm{kg} / \mathrm{m}^{3}\right)$, low birth weight and risk for metabolic syndrome in middleaged men. The association between low birth weight and metabolic syndrome was attenuated in men participating in at least $25 \mathrm{~min}$ of leisure time VPA per week. Similarly results was observed in a study by Erikson et al. (90) in elderly (aged 65 to 75 years). Exercising regularly and with moderate intensity had a protective effect on glucose intolerance in those who were born thin or small $(>3000 \mathrm{~g})$. Physical activity was assessed by self-reports in both studies $(89,90)$. Two studies have examined the modifying effect of objectively assessed physical activity on the association between birth weight and health outcomes in youths, with contrary results $(91,92)$. Ortega et al. (91) suggested that being classified as active (physical activity level above median) attenuated the association between low birth weight and markers of insulin resistance in adolescence. On the other hand, Ridgway et al. (92) found no modifying effect of total physical activity and MVPA on the association between birth weight and fat mass index (FMI $=$ fat mass $[\mathrm{kg}] /$ height $\left[\mathrm{m}^{2}\right]$ ) and waist circumference in 9 to 15 year olds. Furthermore, adjustment for physical activity and MVPA made little changes to the association between low birth weight and insulin resistance. None of the identified studies have adjusted for gestational age (89-92), which may be an important confounding factor (61). Due to conflicting results in the two studies examining the modifying effect of physical activity on the association between birth weight and health outcomes in youth, future studies are needed to explore the role of physical activity and MVPA on these associations.

\section{FUTURE DIRECTIONS}

Physical activity and sedentary time are complex behaviors determined by several factors throughout life (50), and it is possible that also partly modifiable factors acting during the first years of life influence physical activity level and sedentary behaviors in youth. Well characterized birth cohorts are ideally suited to further explore this hypothesis and whether physical activity modify the associations between early life factors with obesity and cardio-metabolic risk factors in youth. The MoBa cohort study is perfectly placed to provide a valuable addition to existing research.

The MoBa study is a prospective population-based pregnancy cohort run by the Norwegian Institute for Public Health (NIPH) (23). The objective of MoBa is to study the causes of disease among mothers and children. All women in Norway who gave birth at maternity units with more than 100 births annually were invited, and $38.5 \%$ consented to participate. The participants were recruited during gestational week 18 , and mother and child are followed-up regularly with postal questionnaires (23). In total, the cohort includes 108000 pregnancies from the inclusion period between 1999 and 2008. Data on weight and length are available at birth and with regular intervals up to the age of 7 years. The mothers were asked to copy data from the children's personal health chart when reporting length/height and weight in the questionnaires. Infant temperament was maternally reported at age 6 months and motor development; e.g. age at walking and standing unaided, were maternally reported at 18 months by standardized questionnaires. The children's leisure time physical activity and sedentary behavior were maternally reported at age 7 years. The mothers were 
asked about their child's leisure time physical activity as frequency and hours per week, and hours per day using TV, DVD, electronic games or computer. At present almost 36000 mothers have answered the 7year follow-up questionnaire. In addition to the selfreported questionnaire data, a sub-cohort including randomly selected children born between July 2002 and December 2003 is currently underway. The subcohort (approximately 500 participants) will provide data on objectively measured physical activity and sedentary time (by accelerometer, Actigraph GT3X+) and anthropometry (height, weight, waist circumference and body composition). The objectively measured physical activity and sedentary time from the subcohort can be used to replicate the findings from the questionnaires, and will therefore contribute to strengthening the inference from the results obtained by self-report. By using this data from the MoBa we can further examine the research questions on the associations between early growth, motor development and infant temperament with physical activity and sedentary time/behaviors in 7 and 10-12 year old children.

\section{CONCLUSION}

There is insufficient evidence to conclude whether any of the included early life factors predicts childhood physical activity and sedentary time. Few studies including a wide variety of possible early life determinants are available, and some are limited by their methodology. Therefore, additional research on possible determinants of physical activity and sedentary time using data from well characterized birth-cohorts are needed to inform evidence based public health interventions.

\section{REFERENCES}

1. Barker DJ, Osmond C, Golding J, Kuh D, Wadsworth ME. Growth in utero, blood pressure in childhood and adult life, and mortality from cardiovascular disease. BMJ 1989; 298(6673):564-7.

2. Barker DJ, Osmond C. Infant mortality, childhood nutrition, and ischaemic heart disease in England and Wales. Lancet 1986;1(8489):1077-81.

3. Gluckman PD, Hanson MA. The developmental origins of health and disease: An overview. In: Gluckman P, Hanson M, editors. Developmental origins of health and disease. Cambridge: Cambridge University Press, 2006: 1-5.

4. Power C, Kuh D, Morton S. From developmental origins of adult disease to life course research on adult disease and aging: insights from birth cohort studies. Annu Rev Public Health 2013;34:7-28.

5. Berenson GS, Srinivasan SR, Bao W, Newman WP, Tracy RE, Wattigney WA. Association between multiple cardiovascular risk factors and atherosclerosis in children and young adults: the Bogalusa Heart Study. $N$ Engl $J$ Med 1998; 338(23):1650-6.

6. Mahoney LT, Burns TL, Stanford W, Thompson BH, Witt JD, Rost CA, et al. Coronary risk factors measured in childhood and young adult life are associated with coronary artery calcification in young adults: the Muscatine Study. J Am Coll Cardiol 1996;27(2):277-84.

7. Frankel S, Elwood P, Sweetnam P, Yarnell J, Smith G. Birthweight, body-mass index in middle age, and incident coronary heart disease. Lancet 1996;348:1478-80.

8. Lawlor D, Ronalds G, Clark H, Smith G, Leon D. Birth weight is inversely associated with incident coronary heart disease and stroke among individuals born in the 1950s: findings from the Aberdeen children of the 1950s prospective cohort study. Circulation 2005;112:1414-8.

9. Barker DJ. Adult consequences of fetal growth restriction. Clin Obstet Gynecol 2006;49(2):270-83.

10. Huxley R, Shiell A, Law C. The role of size at birth and postnatal catch-up growth indetermining systolic blood pressure: a systematic review of the literature. J Hypertens 2000;18(7):815-31.

11. Ravelli AC, van der Meulen JH, Michels RP, Osmond C, Barker DJ, Hales CN, et al. Glucose tolerance in adults after prenatal exposure to famine. Lancet 1998;351(9097):173-7.

12. Norris S, Osmond C, Gigante D, Kuzawa C, Ramakrishnan L, Lee N, et al. Size at birth, weight gain in infancy and childhood, and adult diabetes risk in five low- or middle-income country birth cohorts. Diabetes Care 2012;35(1):72-9.

13. Oken E, Gillman MW. Fetal origins of obesity. Obes Res 2003;11(4):496-506.

14. Godfrey KM. The developmental origins hypothesis: epidemiology. In: Gluckman P, Hanson M, editors. Developmental origins of health and disease. Cambridge: Cambridge University Press, 2006: 6-32.

15. Ekelund U, Ong KK, Linne Y, Neovius M, Brage S, Dunger DB, et al. Association of weight gain in infancy and early childhood with metabolic risk in young adults. J Clin Endocrinol Metab 2007;92(1):98-103.

16. Bekkers MB, Brunekreef B, Smit HA, Kerkhof M, Koppelman GH, Oldenwening M, et al. Early-life determinants of total and HDL cholesterol concentrations in 8-year-old children; the PIAMA birth cohort study. PLoS One 2011;6(9):e25533.

17. Ekelund U, Ong K, Linne Y, Neovius M, Brage S, Dunger DB, et al. Upward weight percentile crossing in infancy and early childhood independently predicts fat mass in young adults: the Stockholm Weight Development Study (SWEDES). Am J Clin Nutr 2006;83(2):324-30. 
18. Ong K, Loos RJ. Rapid infancy weight gain and subsequent obesity: systematic reviews and hopeful suggestion. Acta Paediatr 2006;95:904-8.

19. Ong KK, Ahmed ML, Emmett PM, Preece MA, Dunger DB. Association between postnatal catch-up growth and obesity in childhood: prospective cohort study. BMJ 2000;320(7240):967-71.

20. Baird J, Fisher D, Lucas P, Kleijnen J, Roberts H, Law C. Being big or growing fast: systematic review of size and growth in infancy and later obesity. BMJ 2005;331(7522):929-31.

21. Hallal PC, Wells JC, Reichert FF, Anselmi L, Victora CG. Early determinants of physical activity in adolescence: prospective birth cohort study. BMJ 2006;332(7548):1002-7.

22. Hennekens CH, Buring JE, Mayrent SL. Epidemiology in medicine. Boston: Little, Brown, 1987.

23. Magnus P, Irgens LM, Haug K, Nystad W, Skjaerven R, Stoltenberg C. Cohort profile: the Norwegian Mother and Child Cohort Study (MoBa). Int J Epidemiol 2006;35(5):1146-50.

24. Andersen L, Harro M, Sardinha L, Froberg K, Ekelund U, Brage S, et al. Physical activity and clustered cardiovascular risk in children: a cross-sectional study (The European Youth Heart Study). Lancet 2006;368:299304.

25. Strong WB, Malina RM, Blimkie CJ, Daniels SR, Dishman RK, Gutin B, et al. Evidence based physical activity for school-age youth. J Pediatr 2005;146(6):732-7.

26. Ekelund U, Luan J, Sherar LB, Esliger DW, Griew P, Cooper A. Moderate to vigorous physical activity and sedentary time and cardiometabolic risk factors in children and adolescents. JAMA 2012;307(7):704-12.

27. Ekelund U, Hildebrand M, Collings PJ. Physical activity, sedentary time and adiposity during the first two decades of life. Proc Nutr Soc 2014;73(2):319-29.

28. Hallal PC, Victora C, Azevedo M, Wells J. Adolescent physical acitvity and health: a systematic review. Sports Med 2006;36(12):1019-30.

29. Ekelund U, Brage S, Froberg K, Harro M, Anderssen SA, Sardinha LB, et al. TV viewing and physical activity are independently associated with metabolic risk in children: the European Youth Heart Study. PLoS Med 2006;3(12):e488.

30. Brage S, Wedderkopp N, Ekelund U, Franks P, Wareham N, Andersen L, et al. Features of the metabolic syndrome are associated with objectively measured physical activity and fitness in Danish children. Diabetes Care 2004;27(9):2141-8.

31. Steele R, van Sluijs E, Cassidy A, Griffin S, Ekelund U. Targeting sedentary time or moderate- and vigourosintensity activity: Independent relations with adiposity in a population-based sample of 10-y-old British children. Am J Clin Nutr 2009;90:1185-92.

32. Collings PJ, Brage S, Ridgway CL, Harvey NC, Godfrey KM, Inskip HM, et al. Physical activity intensity, sedentary time, and body composition in preschoolers. Am J Clin Nutr 2013;97(5):1020-8.

33. Mitchell J, Beets M, Nader P. Time spend in sedentary behavior and changes in childhood BMI: a longitudinal study from ages 9 to 15 . Int J Obes 2013;37(1):54-60.

34. Goldfield GS, Saunders TJ, Kenny GP, Hadjiyannakis S, Phillips P, Alberga AS, et al. Screen viewing and diabetes risk factors in overweight and obese adolescents. Am J Prev Med 2013;44(4):364-70.

35. Saunders T, Chaput J-P, Tremblay M. Sedentary behaviour as an emerging risk factor for cardiometabolic disease in children and youth. Can J Diabetes 2014;38:53-61.

36. Tremblay MS, Leblanc AG, Janssen I, Kho ME, Hicks A, Murumets K, et al. Canadian sedentary behaviour guidelines for children and youth. Appl Physiol Nutr Metab 2011;36(1):59-64.

37. Australian Government: Departement of Health. Australia's Physical Activity and Sedentary Behaviour Guidelines, 2014.

38. Helsedirektoratet. Anbefalinger om kosthold, ernæring og fysisk aktivitet. Report No. IS-2170, 2014.

39. Kolle E, Stokke J, Hansen B, Andersen S. Fysisk aktivitet blant 6-, 9-, og 15- åringer i Norge: resultater fra en kartlegging in 2011. Oslo: Helsedirektoratet, Report No. IS-2002, 2012.

40. Troiano RP, Berrigan D, Dodd KW, Masse LC, Tilert T, McDowell M. Physical activity in the United States measured by accelerometer. Med Sci Sports Exerc 2008;40(1):181-8.

41. Nader PR, Bradley RH, Houts RM, McRitchie SL, O'Brien M. Moderate-to-vigorous physical activity from ages 9 to 15 years. JAMA 2008;300(3):295-305.

42. Riddoch CJ, Bo AL, Wedderkopp N, Harro M, Klasson-Heggebo L, Sardinha LB, et al. Physical activity levels and patterns of 9- and 15-yr-old European children. Med Sci Sports Exerc 2004;36(1):86-92.

43. Pate RR, Stevens J, Pratt C, Sallis JF, Schmitz KH, Webber LS, et al. Objectively measured physical activity in sixth-grade girls. Arch Pediatr Adolesc Med 2006;160(12):1262-8.

44. Verloigne M, Lippevelde W, Maes L, Yilidrim M, Chinapaw M, Manios Y, et al. Levels of physical acitivty and sedentary time among 10- to 12-year-old boys and girls across 5 European countries using accelerometers: an observational sudy within the ENERGY-project. Int J Behav Nutr Phys Act 2012;9(34):34.

45. Riddoch CJ, Mattocks C, Deere K, Saunders J, Kirkby J, Tilling K, et al. Objective measurement of levels and patterns of physical activity. Arch Dis Child 2007;92(11):963-9.

46. Owen CG, Nightingale CM, Rudnicka AR, Cook DG, Ekelund U, Whincup PH. Ethnic and gender differences in physical activity levels among 9-10-year-old children of white European, South Asian and African- 
Caribbean origin: the Child Heart Health Study in England (CHASE Study). Int J Epidemiol 2009;38(4): 1082-93.

47. Kolle E, Steene-Johannessen J, Andersen LB, Anderssen SA. Objectively assessed physical activity and aerobic fitness in a population-based sample of Norwegian 9- and 15-year-olds. Scand J Med Sci Sports 2010; 20(1):e41-e47.

48. Bauman AE, Sallis JF, Dzewaltowski DA, Owen N. Toward a better understanding of the influences on physical activity: the role of determinants, correlates, causal variables, mediators, moderators, and confounders. Am J Prev Med 2002;23:5-14.

49. Ainsworth B, Matthews C. Physical activity epidemiology research. In: Thomas J, Nelson J, Silverman S, editors. Research Methods in Physical Activity, 5th edn. Champaign, IL: Human Kinetics, 2005: 301-20.

50. Bauman AE, Reis RS, Sallis JF, Wells JC, Loos RJ, Martin BW. Correlates of physical activity: why are some people physically active and others not? Lancet 2012;380(9838):258-71.

51. Craggs C, Corder K, van Sluijs EM, Griffin SJ. Determinants of change in physical activity in children and adolescents: a systematic review. Am J Prev Med 2011;40(6):645-58.

52. Uijtdewilligen L, Nauta J, Singh AS, van MW, Twisk JW, van der Horst K, et al. Determinants of physical activity and sedentary behaviour in young people: a review and quality synthesis of prospective studies. $\mathrm{Br} J$ Sports Med 2011;45(11):896-905.

53. Pate RR, Mitchell JA, Byun W, Dowda M. Sedentary behaviour in youth. Br J Sports Med 2011;45(11):90613.

54. Hoyos Cillero I, Jago R. Systematic review of correlates of screen-viewing among young children. Prev Med 2010;51(1):3-10.

55. Davison KK, Francis LA, Birch LL. Links between parents' and girls' television viewing behaviors: a longitudinal examination. J Pediatr 2005;147(4):436-42.

56. Andersen L, Ängquist L, Gamborg M, Byberg L, Bengtsson C, Canoy D, et al. Birth weight in relation to leisure time physical activity in adolescence and adulthood: meta-analysis of results from 13 nordic cohorts. PLoS One 2009;4(12):e8192.

57. Campbell CP, Barnett AT, Boyne MS, Soares-Wynter S, Osmond C, Fraser RA, et al. Predictors of physical activity energy expenditure in Afro-Caribbean children. Eur J Clin Nutr 2010;64(10):1093-100.

58. Hallal PC, Dumith SC, Ekelund U, Reichert FF, Menezes AM, Victora CG, et al. Infancy and childhood growth and physical activity in adolescence: prospective birth cohort study from Brazil. Int J Behav Nutr Phys Act 2012;9:82.

59. Mattocks C, Ness A, Deere K, Tilling K, Leary S, Blair S, et al. Early life determinants of physical activity in 11 to 12 year olds: cohort study. BMJ 2008;336(7634):26-9.

60. Pearce MS, Basterfield L, Mann KD, Parkinson KN, Adamson AJ, Reilly JJ. Early predictors of objectively measured physical activity and sedentary behaviour in 8-10 year old children: the Gateshead Millennium Study. PLoS One 2012;7(6):e37975.

61. Ridgway C, Brage S, Sharp S, Corder K, Westgate K, van Sluijs E, et al. Does birth weight influence physical activity in youth? A combined analysis of four studies using objectively measured physical activity. PLoS One 2011;6(1):e16125.

62. Wijtzes AIM, Kooijman MNM, Kiefte-de Jong JCP, de Vries SIP, Henrichs JP, Jansen WP, et al. Correlates of Physical Activity in 2-Year-Old Toddlers: the Generation R Study. J Pediatr 2013;163(3):791-799.

63. Ridgway C, Ong K, Tammelin T, Sharp S, Ekelund U, Jarvelin M-R. Infant motor development predicts sports participation at age 14 years: Northern Finland birth cohort of 1966. PLoS One 2009;4(8):e6837.

64. Thompson A, Adair L, Bentley M. Maternal characteristics and preception of temperament associated with infant TV exposure. Pediatrics 2013;131(2):e390-e397.

65. Baker MS, Li G, Kohorst JJ, Waterland RA. Fetal growth restriction promotes physical inactivity and obesity in female mice. Int J Obes 2013: 1-7.

66. Bellinger L, Sculley DV, Langley-Evans SC. Exposure to undernutrition in fetal life determines fat distribution, locomotor activity and food intake in ageing rats. Int J Obes 2006;30(5):729-38.

67. Vickers MH, Breier BH, McCarthy D, Gluckman PD. Sedentary behavior during postnatal life is determined by the prenatal environment and exacerbated by postnatal hypercaloric nutrition. Am J Physiol Regul Integr Comp Physiol 2003;285(1):R271-R273.

68. Kaseva N, Wehkalampi K, Strang-Karlsson S, Salonen M, Pesonen AK, Raikkonen K, et al. Lower conditioning leisure-time physical activity in young adults born preterm at very low birth weight. PLoS One 2012; 7(2):e32430.

69. Kajantie E, Strang-Karlsson S, Hovi P, Räikkönen K, Pesonen AK, Heinonen K, et al. Adults born at very low birth weight exercise less than their peers born at term. J Pediatr 2010;157(4):610-6.

70. Rogers M, Fay TB, Whitfield MF, Tomlinson J, Grunau RE. Aerobic capacity, strength, flexibility, and activity level in unimpaired extremely low birth weight $(\leq 800 \mathrm{~g})$ survivors at 17 years of age compared with term-born control subjects. Pediatrics 2005;116(1):e58-e65.

71. Trost SG, Loprinzi PD, Moore R, Pfeiffer KA. Comparison of accelerometer cut points for predicting activity intensity in youth. Med Sci Sports Exerc 2011;43(7):1360-8. 
72. Pate RR, O'Neill JR, Lobelo F. The evolving definition of "sedentary". Exerc Sport Sci Rev 2008;36(4):173-8.

73. Lucas A, Fewtrell MS, Cole TJ. Fetal origins of adult disease-the hypothesis revisited. BMJ 1999;319(7204): 245-9.

74. Kwon S, Janz KF, Burns TL, Levy SM. Effects of adiposity on physical activity in childhood: Iowa Bone Development Study. Med Sci Sports Exerc 2011;43(3):443-8.

75. Richmond RC, Davey SG, Ness AR, den HM, McMahon G, Timpson NJ. Assessing causality in the association between child adiposity and physical activity levels: a Mendelian randomization analysis. PLoS Med 2014;11(3):e1001618.

76. Piek JP. Infant motor development. Champaign, Ill.: Human Kinetics, 2006.

77. Stodden DF, Goodway JD, Langendorfer SJ, Roberton MA, Rudisill ME, Garcia C, et al. A developmental perspective on the role of motor skill competence in physical activity: an emergent relationship. Quest 2008; 60(2):290-306.

78. Ridgway C, Ong K, Tammelin T, Sharp S, Ekelund U, Jarvelin M-R. Birth size, infant weight gain, and motor development influence adult physical performance. Med Sci Sports Exerc 2009;41(6):1212-21.

79. Kuh D, Hardy R, Butterworth S, Okell L, Richards M, Wadsworth M, et al. Developmental origins of midlife physical performance: evidence from a British birth cohort. Am J Epidemiol 2006;164(2):110-21.

80. Kuh D, Hardy R, Butterworth S, Okell L, Wadsworth M, Cooper C, et al. Developmental origins of midlife grip strength: findings from a birth cohort study. J Gerontol A Biol Sci Med Sci 2006;61(7):702-6.

81. Rothbart MK, Bates J. Temperament. In: Eisenberg N, editor. Handbook of Child Psychology, 6th edn. Hoboken, New Jersey: John Wiley \& Sons; 2006: 99-166.

82. Darlington A-S, Wright C. The influence of temperament on weight gain in early infancy. J Dev Behav Pediatr 2006;27(4):329-35.

83. Slining M, Adair L, Goldman B, Borja J, Bentley M. Infant temperament contributes to early infant growth: a prospective cohort of African American infants. Int J Behav Nutr Phys Act 2009;6(51).

84. Bergmeier H, Skouteris H, Horwood S, Hooley M, Richardson B. Associations between child temperament, maternal feeding practices and child body mass index during the preschool years: a systematic review of the literature. Obesity Reviews 2014;15(1):9-18.

85. Niegel S, Ystrom E, Vollrath M. Is difficult temperament related to overweight and rapid early weight gain in infants? A prospective cohort study. J Dev Behav Pediatr 2007;28:462-6.

86. Agras WS, Hammer LD, McNicholas F, Kraemer HC. Risk factors for childhood overweight: a prospective study from birth to 9.5 years. J Pediatr 2004;145(1):20-5.

87. Vollrath ME, Tonstad S, Rothbart MK, Hampson SE. Infant temperament is associated with potentially obesogenic diet at 18 months. Int J Pediatr Obes 2011;6(2-2):e408-e414.

88. Vollrath ME, Stene-Larsen K, Tonstad S, Rothbart MK, Hampson SE. Associations between temperament at age 1.5 years and obesogenic diet at ages 3 and 7 years. J Dev Behav Pediatr 2012;33(9):721-7.

89. Laaksonen DE, Hanna-Maaria L, Lynch J, Lakka TA. Cardiorespiratory fitness and vigorous leisure-time physical activity modify the association of small size at birth with the metabolic syndrome. Diabetes Care 2003;26(7):2156-64.

90. Eriksson JG, Ylihärsilä H, Forsèn T, Osmond C, Barker DJP. Exercise protects against glucose intolerance in individuals with a small body size at birth. Prev Med 2004;39(1):164-7.

91. Ortega FB, Ruiz JR, Hurtig-Wennlöf A, Meirhaeghe A, Gonzàlez-Gross M, Moreno LA, et al. Physical activity attenuates the effect of low birth weight on insulin resistance in adolescents: findings from two observational studies. Diabetes 2011;60(9):2295-9.

92. Ridgway CL, Brage S, Anderssen SA, Sardinha LB, Andersen LB, Ekelund U. Do physical activity and aerobic fitness moderate the association between birth weight and metabolic risk in youth? The European Youth Heart Study. Diabetes Care 2011;34(1):187-92. 